\title{
粘塑性・クリープ分離型構成モデルの鉛フリーはんだへの適用*
}

\author{
林 丈晴 ${ }^{* 1,2}$, 海老原理徳 ${ }^{* 3}$, 浅井竜彦*4, 渡邊裕彦 ${ }^{* 4}$
}

\section{Application of Viscoplastic-Creep Separate Constitutive Model to Lead-Free Solder Alloy}

\author{
Takeharu HAYASHI ${ }^{*}$, Yoshinori EBIHARA, Tatsuhiko ASAI and Hirohiko WATANABE \\ ${ }^{* 1}$ Tokyo Metroporitan Koganei Technical High school \\ Hon-cho 6-8-9, Koganei-shi, Tokyo, 184-8501 Japan
}

\begin{abstract}
When we estimate the fatigue life of lead-free solder joints, we have to conduct FE analysis using a constitutive model which can exhibit mechanical properties of lead-free solder. In FE analysis of solder joints under cyclic temperature load, a constitutive model has to express stress strain curves, stress strain hysteresis loops and stress relaxation curves accurately, containing these temperature dependencies and these rate dependencies. In this study, we proposed a separate type viscoplastic-creep constitutive model which can describe stress strain curves, stress strain hysteresis loops and stress relaxation curves, with these temperature dependencies and these rate dependencies. We implemented the proposed model into finite element analysis code ABAQUS. We conducted tensile tests, tension-compression tests and tension-stress relaxation tests of $\mathrm{Sn} 3.5 \mathrm{Ag} 0.5 \mathrm{Cu} 0.07 \mathrm{Ni} 0.01 \mathrm{Ge}$ solder and determined material parameters of the proposed model from tensile test data and tension-compression test data. Then, we analyzed the conducted material tests using the proposed model and compared FE analysis results with experimental test data to examine the validity of the proposed model. It was confirmed that analytical results were in good agreements with the experimental ones.
\end{abstract}

Key Words : Stress Relaxation, Creep, Constitutive Equation, Finite Element Method, Lead-Free Solder, Viscoplasticity

\section{1. 緒言}

近年, 電子機器の小型化, 高密度化に伴って，微細はんだ実装技術の開発が進められている.また，地球環境 保護の観点から，鉛フリーはんだを使用したはんだ実装が進展している。これらの電子部品はんだ接合部では， 電源の $\mathrm{ON}$ ・ $\mathrm{OFF}$ などによる周期的な温度環境下で，構成材料の線膨張係数の違いに基づく変位のミスマッチによ り，低サイクルの周期的な熱変形がはんだ接合部に生じ，疲労破壊が生じる。従って高密度はんだ実装技術の開 発では，はんだ接合部の熱疲労寿命評価が重要な検討課題である.

一般に，温度サイクル負荷を受けるはんだ接合部の熱疲労寿命評価は次のプロセスで行われる．まず，機械的 疲労試験などによりはんだの疲労寿命特性を求めるとともに，寿命評価を行うはんだ接合部について，有限要素 法による構造解析を行って，寿命評価で用いるパラメータを求める. 次にこのパラメータと疲労寿命特性から疲 労寿命を求める. 従って，はんだ接合部の熱疲労寿命評価では，はんだの非弾性変形を正確に表現する構成モデ ルを用いた有限要素解析技術の開発が重要である.

はんだの低ひずみ速度における非弾性変形では, クリープ変形は塑性履歴に依存し，塑性変形はクリープ履歴 に依存することから, 塑性特性を高ひずみ速度の引張試験から取得し, クリープ特性をクリープ試験から取得す る古典的な塑性・クリープ分離モデルでは，この相互作用をあらわすことができない(1). 統一型粘塑性構成モデ ルでは, この塑性変形とクリープ変形の相互作用を表現することが可能で多くのモデルが提案されている(1) (10). この中には例えば，降伏曲面を使用しない統一型粘塑性構成モデル ${ }^{(2)}$ や疲労損傷の影響を組み込んだ統一型粘塑 性構成モデル(3) 〜(6) などがある. 一方, 統一型粘塑性構成モデルでは式が複雑となり, 試験結果から材料パラメ 一タを決定するのが容易ではない(10). そこで, 非弾性ひずみを過渡成分と定常成分に分離する粘塑性構成モデル

* 原稿受付 2011 年 5 月 11 日

${ }^{* 1}$ 正員，東京都立小金井工業高等学校（广184-8581 東京都小金井市本町 6-8-9）

*2 東京学芸大学大学院

*3 正員, 東京学芸大学

*4 富士電機(株)

E-mail: r079003g@u-gakugei.ac.jp 
(10) (11)や，それぞれの引張試駼結果から非弾性ひずみをクリープひずみ成分と塑性ひずみ成分に分離する数值手 法を用いた塑性・クリープ分離モデル(12) (13)が開発され，はんだ材料に適用されている.

図 1 に示す温度サイクル負荷を受けるはんだ接合部の有限要素解析で，はんだの構成モデルが表現すべき力学 的特性は, 温度上昇, 高温保持, 温度降下および低温保持のそれぞれの温度負荷で生ずる力学的特性である. 本 研究では温度上昇および温度降下時に生ずる力学的特性と高温および低温保持時に生ずる力学的特性に分けて構 成モデルを作成した．具体的には，これらの力学的特性と機械的試験法との関連から温度上昇および温度降下時 に生ずる力学的特性としては, 応力ひずみ曲線と応力ひずみヒステリシスループがある.はんだではこれらの力 学的特性にひずみ速度依存性および温度依存性が顕著で, 構成モデルは，これらのひずみ速度依存性および温度 依存性を正確に表現する必要がある.また, 温度保持時において生ずる力学的特性としては応力緩和曲線があり, 構成モデルはこの応力緩和特性とその温度依存性も正確に表現しなければならない. 本研究では, 応力ひずみ曲線, 応力ひずみヒステリシスループおよび応力緩和曲線を正確に表現でき, 材料パラメータの決定も容易な, 粘塑性・ クリープ分離型構成モデルを提案した。従来の研究では, 温度サイクル負荷に着目して, 温度上昇および温度降 下時に生ずる力学的特性と温度保持時に生ずる力学的特性をよく表現するものとしてはんだの構成モデルを作成 した研究は少ない，さらに温度依存性およびひずみ速度依存性を考慮した機械的試験を実施して，構成モデルの 材料パラメータ決定法を明確に示した点も本研究の特徵である.

本研究では, これらの力学的特性を明確に表現するために, 非弾性ひずみを, 応力ひずみ曲線の過渡領域およ び応力ひずみヒステリシスループを表現する粘塑性ひずみ成分と, 応力ひずみ曲線の応力収束值と応力緩和曲線 を表現するクリープひずみ成分に分離した構成モデルを提案し, このモデルを汎用有限要素解析プログラム

ABAQUS に組込んだ。さらに, Sn3.5Ag0.5Cu0.07Ni0.01Ge はんだの引張試験と引張圧縮試験を温度およびひずみ 速度を変えて実施し, 本構成モデルの材料パラメータを決定した. また, 本構成モデルと決定した材料パラメー 夕を用いて, 引張試験, 引張圧縮試験および引張・応力緩和試験の有限要素解析を行い, 解析結果と試験結果を 比較して，本構成モデルの妥当性を検討した.

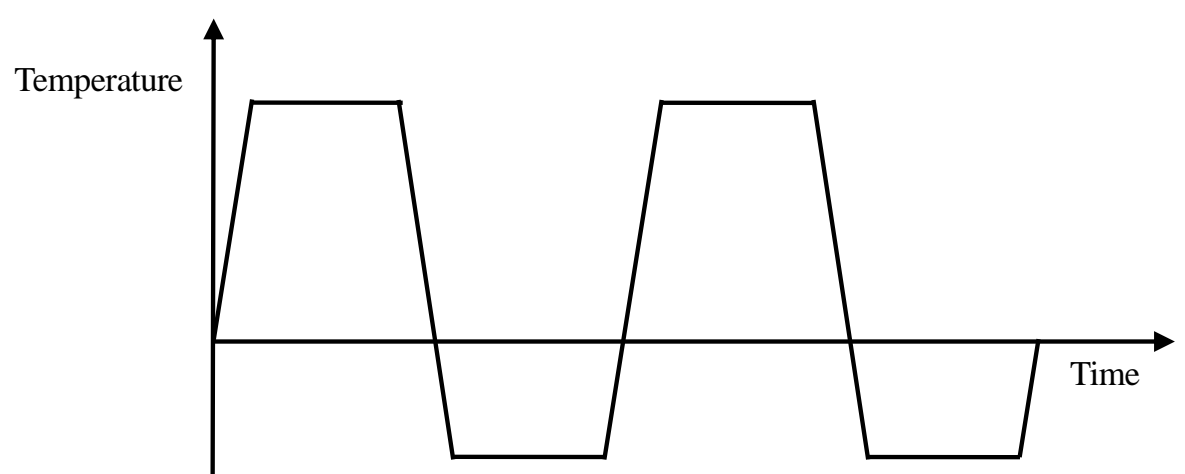

Fig. 1 Typical cyclic temperature load in accelerated damage test

\section{2. 構成モデル}

本構成モデルでは, 非弾性ひずみテンソル $\varepsilon_{i j}^{i n}$ は, 式(1)のように粘塑性ひずみテンソル $\varepsilon^{v p}{ }_{i j}$ とクリープひず みテンソル $\varepsilon^{c}{ }_{i j}$ の和で表す. また, 粘塑性ひずみ速度テンソル $\varepsilon^{v_{i j}}$ とクリープひずみ速度テンソル $\varepsilon^{c}{ }_{i j}$ をそれぞ れ式(2), 式(3)で表す.なお, 粘塑性ひずみ速度テンソル $\varepsilon^{\cdot p_{i j}}$ は過応力理論に基づく. 過応力理論では, 図 2 に 示すように, ひずみの増加に伴い, 応力点が応力空間の原点から降伏曲面の外一移動し, 降伏曲面から離れ続 ける. 応力点と降伏曲面の距離がある值に達した後, その距離を保ちながらひずみが増加する. 以後, この距 離を限界距離と記す，粘塑性変形における応力ひずみ関係は, 限界距離および降伏曲面の挙動によって決定さ れる.

$$
\varepsilon^{i n}{ }_{i j}=\varepsilon^{v p}{ }_{i j}+\varepsilon^{c}{ }_{i j}
$$




$$
\begin{gathered}
\dot{\varepsilon}^{\dot{v p}}{ }_{i j}=A(\dot{\varepsilon})^{L}\langle\Delta \sigma\rangle^{n} \exp \left(-\frac{k}{\left\{p_{1} \operatorname{sign}\left(T-T_{a}\right)\left|T-T_{a}\right|^{p_{2}}+T_{a}\right\}}\right) n_{i j}{ }^{a} \\
\dot{\varepsilon}^{\dot{c}}{ }^{i j}=A_{c} \sigma^{n_{c}} n_{i j}{ }^{b}
\end{gathered}
$$

ただし，式(2)でく＞は Macauley の括弧で $x<0$ ならく $x>=0, x \geqq 0$ ならく $x>=x$ である. $n_{i j}{ }^{a}$ は過応力に対す る流れテンソル $n_{i j}{ }^{b}$ は応力に対する流れテンソル,$\dot{\varepsilon}$ はひずみ速度, $T$ は絶対温度, $\Delta \sigma$ は相当過応力, $\sigma$ は相当 応力, $n$ は応力指数, $A, L, k$ は材料パラメータ, $A_{c}$ はクリープ定数, $n_{c}$ はクリープ指数である. 本構成モデル では，材料パラメータを決定する際に基準となる温度および基準となるひずみ速度を選択する． $T_{a}$ は基準となる 温度である.また， $p_{1}, p_{2}$ はそれぞれ式(4), 式(5)で表す。

$$
\begin{aligned}
& p_{1}=\kappa+D \operatorname{sign}\left(\frac{\dot{\varepsilon}_{a}-\dot{\varepsilon}}{2 \dot{\varepsilon}_{a}\left(\dot{\varepsilon}+\dot{\varepsilon}_{a}\right)}\right)\left|\frac{\dot{\varepsilon}_{a}-\dot{\varepsilon}}{2 \dot{\varepsilon}_{a}\left(\dot{\varepsilon}+\dot{\varepsilon}_{a}\right)}\right|^{u} \\
& p_{2}=m-F \operatorname{sign}\left(\frac{\dot{\varepsilon}_{a}-\dot{\varepsilon}}{2 \dot{\varepsilon}_{a}\left(\dot{\varepsilon}+\dot{\varepsilon}_{a}\right)}\right)\left|\frac{\dot{\varepsilon_{a}-\dot{\varepsilon}}}{2 \dot{\varepsilon}_{a}\left(\dot{\varepsilon}+\dot{\varepsilon}_{a}\right)}\right|^{s}
\end{aligned}
$$

ただし $, \kappa, m, D, F, u, s$ は材料パラメータであり, $\dot{\varepsilon}_{a}$ は基準となるひずみ速度である.

ここで，相当過応力 $\Delta \sigma$ は式(6)で表される.

$$
\Delta \sigma=\sqrt{3 / 2\left(s_{i j}-\alpha_{i j}{ }^{\prime}\right):\left(s_{i j}-\alpha_{i j}{ }^{\prime}\right)}-r_{0}
$$

ただし， $s_{i j}$ は偏差応力テンソル， $\alpha_{i j}{ }^{\prime}$ は偏差背応力テンソル， $r_{0}$ は降伏曲面の半径である. 本構成モデルでは背 応力の移行式として式(7)の Armstrong-Frederick 則 ${ }^{(14)}$ を用いる.

$$
\dot{\alpha}_{i j}=\frac{2}{3} C \varepsilon^{i p}{ }_{i j}-\beta \alpha_{i j} \dot{p}
$$

ただし， $\alpha_{i j}$ は背応力テンソル $, C, \beta$ は材料パラメータである. また $\dot{p}$ は相当粘塑性ひずみ速度であり式(8)で表 される.

$$
\dot{p}=\sqrt{\frac{2}{3} \varepsilon^{\dot{v p}_{i j}}: \varepsilon^{\dot{v p}}{ }_{i j}}
$$

ここで，粘塑性材料パラメータ $\eta^{(5)}$ を式(9)で表せば，粘塑性ひずみ速度テンソル $\varepsilon^{i p}{ }_{i j}$ は式(10)で表される.

$$
\begin{gathered}
\eta=\frac{1}{A(\dot{\varepsilon})^{L}} \exp \left(\frac{k}{\left.\left|p_{1} \operatorname{sign}\left(T-T_{a}\right)\right| T-\left.T_{a}\right|^{p_{2}}+T_{a}\right\}}\right) \\
\dot{\varepsilon}^{v p}{ }_{i j}=\frac{\langle\Delta \sigma\rangle^{n}}{\eta} n_{i j}{ }^{a}
\end{gathered}
$$




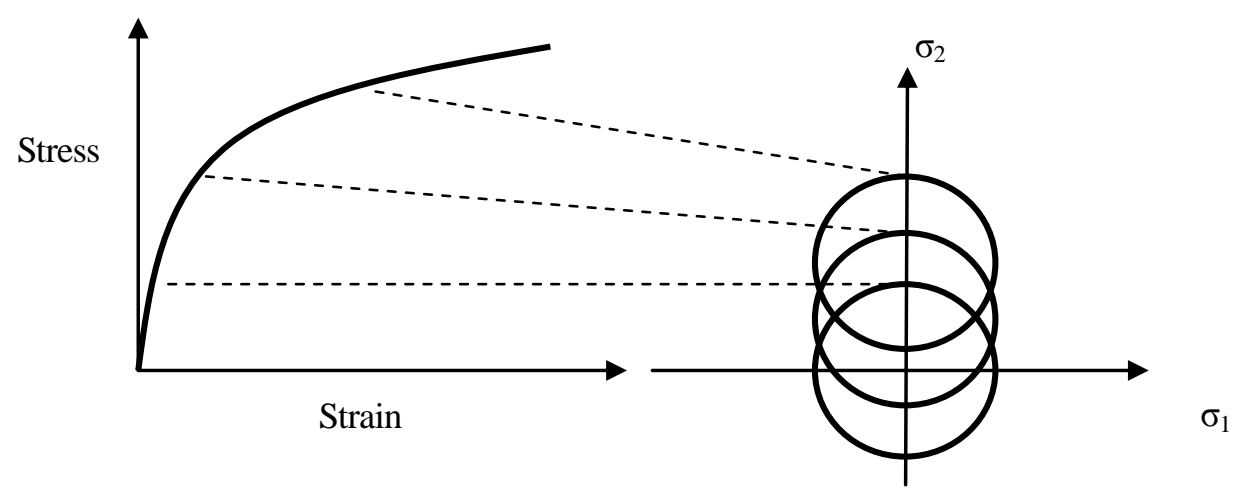

Fig. 2 Evolution of yield surface by overstress model with kinematic hardening rule

\section{3. 材料パラメータの決定}

\section{$3 \cdot 1$ 材料試験}

材料パラメータを決定するために Sn3.5Ag0.5Cu0.07Ni0.01Ge はんだを用いて引張試験および引張土縮試験を行った.さ らに後に本構成モデルの妥当性を検討するために引張・応力緩和試験も行った。使用した試験片の形状と寸法を図 $3($ a)に 示寸.

引張試験は温度 298K，348K，398K，ひずみ速度 0.002\%/sec，0.2\%/sec の計 6 条件で5\%のひずみが生じるまで行った. 引 張土縮式験は温度 298K，348K，398K とし，ひずみ振幅 $1 \%$ ，ひずみ速度 $0.02 \% / \mathrm{sec}$ の両振り三角波で 3 サイクル試験を行

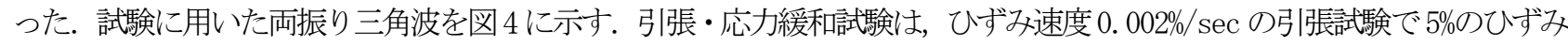
が生じた後，40 分間ひずみを保持して行った. なお，ひずみの測定にはひずみゲージ式伸び計を使用した.

またヤング率は, 図 3(b) の試験片に引張荷重を与え, ひずみ $0.005 \%$ 以を弾性範井として, ひずみゲージを用いて測定 した. 求めたヤング率を表 1 に示す.

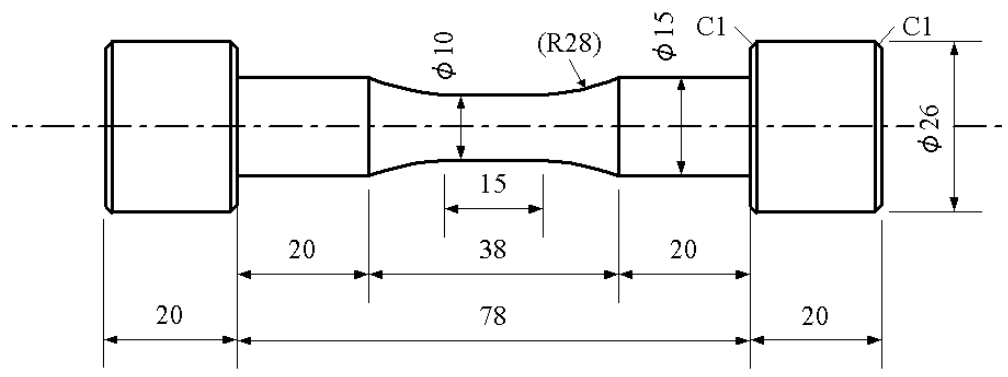

(a) Test specimen for determination of material parameters

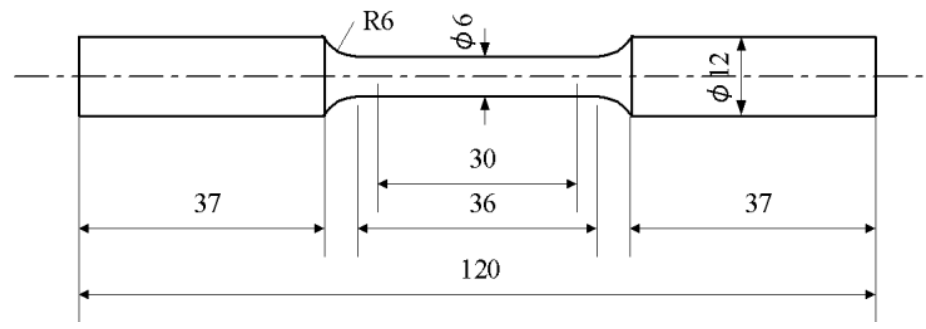

(b) Test specimen for determination of Young's modulus

Fig. 3 Shape and dimensions of specimen 


\section{$3 \cdot 2$ 材料パラメータの決定とその手順}

材料パラメータは，引張試験および引張圧縮試験で得られた応力ひずみ曲線および応力ひずみヒステリシスル ープから求めた．材料パラメータの決定手順を以下に示す.

i ）低ひずみ速度の引張試験で応力が収束した領域はクリープ試験の定常クリープ域と等価と考え ${ }^{(13)}$, 引張試験 結果の応力収束域におけるひずみ速度 $\dot{\varepsilon}$ と応力収束值 $\sigma_{\lim }$ が式(11)の Norton 則で表されるとして, クリープ定数 $A_{c}$ およびクリープ指数 $n_{c}$ を決定する.

$$
\dot{\varepsilon}=A_{c} \sigma_{\lim }^{n_{c}}
$$

ii ）基準となる試験結果を 1 つ選択し，試験開始直後の比例限度の $1 / 20$ 程度を $r_{0}$ として仮決定する. ここで, この試験結果の温度およびひずみ速度をそれぞれ基準となる温度および基準となるひずみ速度とする，なお，本 研究では基準となる温度と基準となるひずみ速度をそれぞれ $298 \mathrm{~K} ， 0.2 \% / \mathrm{sec}$ とした。

iii）ｉ） ii）で決定した材料パラメータを用いて，基準となる試験結果における試験開始直後の比例限度から

$A(\dot{\varepsilon})^{L} \exp \left(-k / T_{a}\right)$ を求め, 比例限度以後のカーブフィッティングから $n, \beta, C$ を決定する. ただし, 材料パラメ

一タ $C$ は各試験条件の試験結果毎に決定する.

iv）基準となる温度の，異なるひずみ速度の試験結果から，i）～iii）で決定した材料パラメータを用いてカーブ

フィッティングにより $A \exp \left(-k T_{a}\right)$ を求め, $L, C$ を決定する. なお，ひずみ速度 $0.02 \% / \mathrm{sec}$ のヤング率は，表 1 のひずみ速度 $0.2 \% / \mathrm{sec}$ の值とひずみ速度 $0.002 \% / \mathrm{sec}$ の值から 1 次補間して求めた。 ここで, 良好なカーブフ イッティングが行えなければii）へ戻る.

v） $k$ を仮決定し, この $k$ と先に求めた $A \exp \left(-k T_{a}\right)$ より $A$ を決定する.

vi）基準となるひずみ速度の，異なる温度の試験結果から，i ）～iv) で決定した材料パラメータを用いてカーブ フィッティングにより $\kappa, m, C$ を決定する.

vii） iii） iv）vi）で未使用の試験結果から i ）～v）で決定した材料パラメータを用いてカーブフィッティングによ りそれぞれのひずみ速度における $p_{1}, p_{2}$ を求め， $C$ を決定する．ここで，良好なカーブフィッティングが行えな ければv）へ戻る.

viii） vii）で求めた $p_{1}, p_{2}$ と vi）で決定した $\kappa, m$ から $D, F, u, s$ を決定する.

また, 材料パラメータ $C$ を, 求めた值から温度 $T$ とひずみ速度 $\dot{\varepsilon}$ の関数として式(12)で表した. 決定したクリ 一プ特性に関する材料パラメータを表 2 に, 粘塑性特性に関する材料パラメータを表 3 にそれぞれ示す.

$$
\begin{aligned}
C= & \left(-1792.66 T^{2}+1060910 T-140644213.6\right) \times \dot{\varepsilon}^{1.62}+(9.126 T-5782 T+917110) \times \dot{\varepsilon}^{0.81} \\
& +\left(0.014618 T^{2}-14.6584 T+3649\right)
\end{aligned}
$$

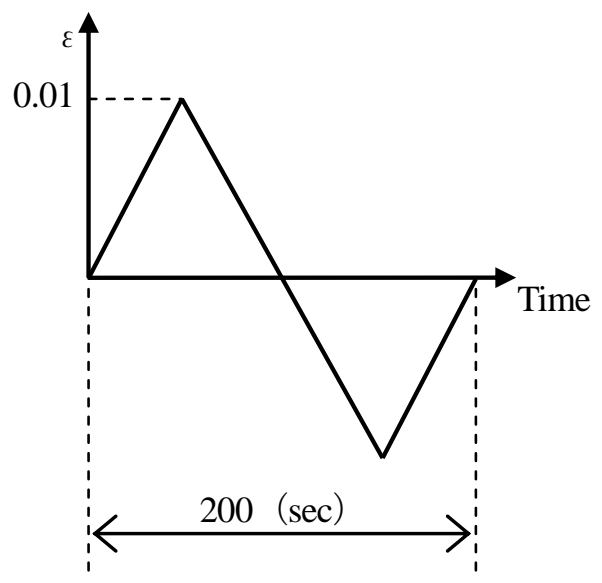

Fig. 4 Triangular wave used in tension-compression tests 
Table 1 Young's modulus

\begin{tabular}{|c|c|c|}
\hline \multirow{2}{*}{$(\% / \mathrm{sec})$} & $T(\mathrm{~K})$ & Young's modulus (GPa) \\
\hline \multirow{3}{*}{0.2} & 298 & 49.1 \\
\cline { 2 - 3 } & 348 & 40.4 \\
\cline { 2 - 3 } & 398 & 37.8 \\
\hline \multirow{3}{*}{0.002} & 298 & 44.7 \\
\cline { 2 - 3 } & 348 & 40.1 \\
\cline { 2 - 3 } & 398 & 35.1 \\
\hline
\end{tabular}

Table 2 Material parameters of creep deformation

\begin{tabular}{|c|c|c|}
\hline Temparature $(\mathrm{K})$ & $A_{c}(1 /(\mathrm{MPa} \cdot \mathrm{sec}))$ & $n_{c}$ \\
\hline 298 & $8.13 \times 10^{-21}$ & 10.74 \\
\hline 348 & $4.37 \times 10^{-16}$ & 8.34 \\
\hline 398 & $1.62 \times 10^{-14}$ & 8.26 \\
\hline
\end{tabular}

Table 3 Material parameters of viscoplastic deformation

\begin{tabular}{|c|c|}
\hline$n$ & 1.21 \\
\hline$A(1 /(\mathrm{MPa} \cdot \mathrm{sec}))$ & $8.30 \times 10^{12}$ \\
\hline$L$ & 0.965 \\
\hline$k(\mathrm{~K})$ & $1.00 \times 10^{4}$ \\
\hline$\kappa$ & $1.01 \times 10^{-4}$ \\
\hline$m$ & 2.26 \\
\hline$D$ & $1.38 \times 10^{-54}$ \\
\hline$F$ & $2.01 \times 10^{-50}$ \\
\hline$s$ & 20.75 \\
\hline$u$ & 21.61 \\
\hline$r_{0}(\mathrm{MPa})$ & 1.00 \\
\hline$\beta$ & 145 \\
\hline
\end{tabular}

\begin{tabular}{|c|c|c|}
\hline \multirow{9}{*}{$C(\mathrm{MPa})$} & \multirow{3}{*}{$\dot{\varepsilon}=0.2 \% / \mathrm{sec}$} & $1300(\mathrm{~T}=298 \mathrm{~K})$ \\
\hline & & $870(\mathrm{~T}=348 \mathrm{~K})$ \\
\hline & & $430(\mathrm{~T}=398 \mathrm{~K})$ \\
\hline & \multirow{3}{*}{$\dot{\varepsilon}=0.002 \% / \mathrm{sec}$} & $600(\mathrm{~T}=298 \mathrm{~K})$ \\
\hline & & $340(\mathrm{~T}=348 \mathrm{~K})$ \\
\hline & & $190(\mathrm{~T}=398 \mathrm{~K})$ \\
\hline & \multirow{3}{*}{$\dot{\varepsilon}=0.0002 \% / \mathrm{sec}$} & $580(\mathrm{~T}=298 \mathrm{~K})$ \\
\hline & & $320(\mathrm{~T}=348 \mathrm{~K})$ \\
\hline & & $140(\mathrm{~T}=398 \mathrm{~K})$ \\
\hline
\end{tabular}

\section{4. 有限要素解析}

\section{4-1 解析方法}

本構成モデルと決定した材料パラメータを用いて，3・1 節で述べた引張試験，引張圧縮試験および引張・応力 緩和試験の有限要素解析を行った。解析は汎用有限要素解析プログラム ABAQUS を用い，開発した構成モデル をユーザーサブルーチンUMAT に書き込んで行った. 使用要素は 8 節点軸対称要素である. 解析では, 試験片平 行部を図 5 に示すように軸対称でモデル化し, 解析対象の下部を固定し, 解析対象の上部に強制変位を与えた.

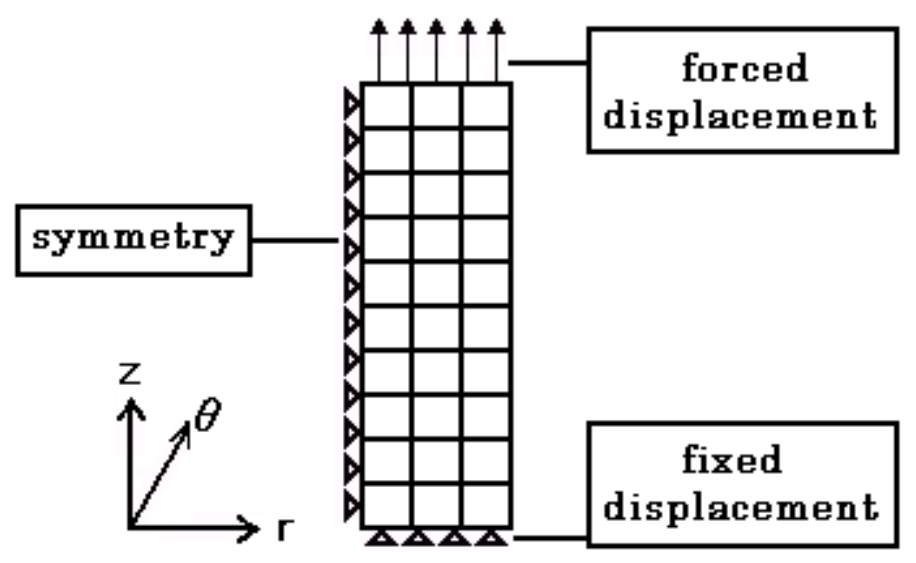

Fig. 5 Finite element mesh of test specimen 


\section{$4 \cdot 2$ 解析結果および考察}

引張試験とその有限要素解析の結果を図 6 に, 引張圧縮試験とその有限要素解析の結果を図 7 に, 引張・応力 緩和試験とその有限要素解析の結果を図 8 にそれぞれ示寸．いずれも解析結果と試験結果がよく一致した。ただ し,引張圧縮試験結果で, 2 サイクル目, 3 サイクル目のヒステリシスループは 1 サイクル目と同一であったため,

図 7 では 1 サイクル目の結果のみ示した.

引張試験と有限要素解析の結果がよく一致したのは, 限界距離および降伏曲面の挙動を温度およびひずみ速度 に対応してよく制御できたことによる．限界距離および降伏曲面の挙動を決定するパラメータのうち，温度およ びひずみ速度に依存するパラメータはそれぞれ粘塑性材料パラメータ $\eta$ と材料パラメータ $C$ である. 本研究では 粘塑性材料パラメータ $\eta$ に温度およびひずみ速度に関する式(9)を導入し，材料パラメータ $C$ を温度およびひず み速度に関する式(12)で表したことにより，温度およびひずみ速度に対応して，限界距離および降伏曲面の挙動 をよく制御できたためと考える，また，非弾性ひずみ成分を粘塑性成分とクリープ成分に分離した結果，式（3） より引張試験から得た応力収束值が, 有限要素解析における応力の限界值として反映されるため, 試験結果の力 ーブフィッティングが容易になった.

引張圧縮試験と有限要素解析の結果がよく一致したのは，過応力理論および移動硬化則を使用したこと，さら に限界距離および降伏曲面の挙動を温度およびひずみ速度に対応してよく制御できたことによる．過応力理論を 用いることにより, 繰り返し変形において, ひずみが累積されるにつれ再降伏後の応力勾配が 0 に漸近するのを 避け，試験結果に適合した応力ひずみ関係を表現することができる．また，移動硬化則を使用することにより， バウシンガー効果を表すことができる.

応力緩和曲線と有限要素解析の結果がよく一致したのは, 本構成モデルではひずみ保持時の非弾性ひずみはク リープひずみのみで表されることと, 応力収束值から得たクリープ特性が応力緩和曲線から得られるであろうク リープ特性と比較的よく一致しているためと考える.

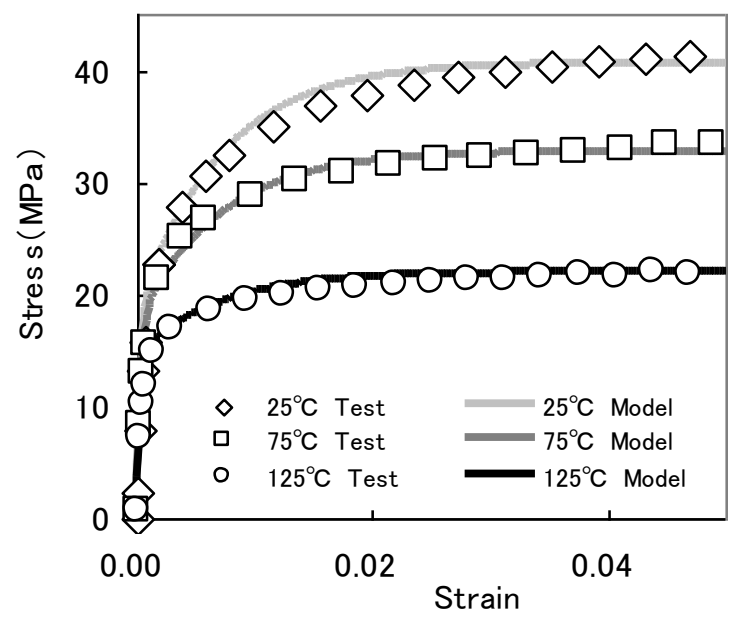

(a) $\dot{\dot{\varepsilon}}=0.2 \% / \mathrm{sec}$

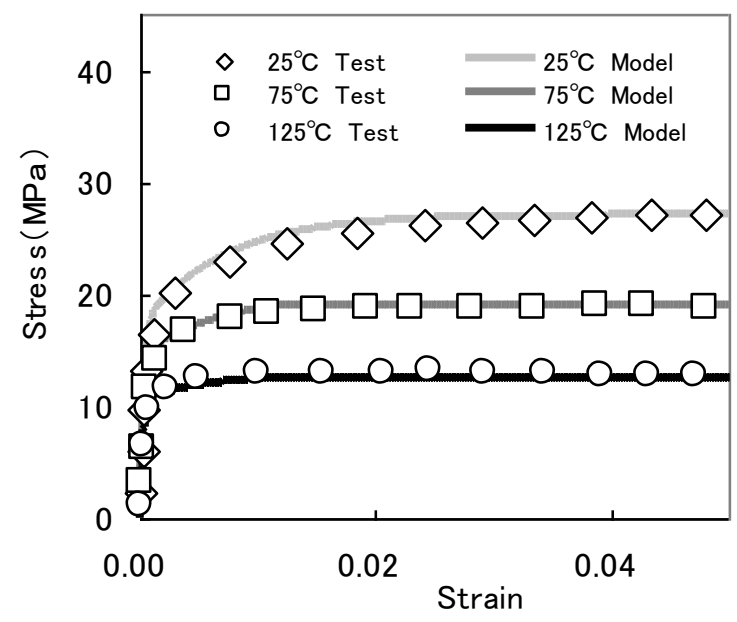

(b) $\dot{\varepsilon}=0.002 \% / \mathrm{sec}$

Fig. 6 Comparison of tension stress-strain relations by FE analyses with those by tests 


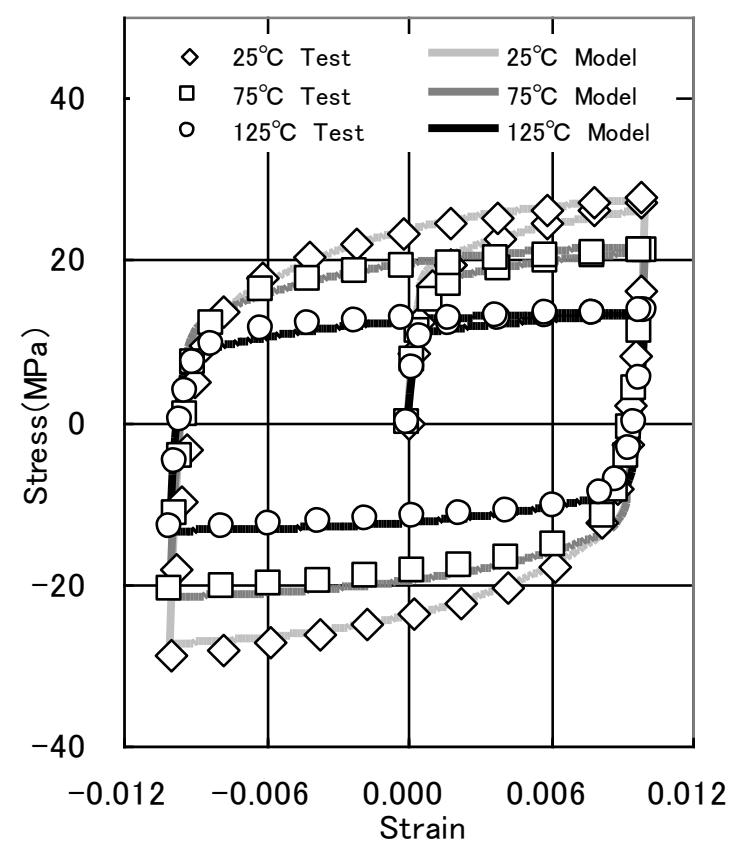

Fig. 7 Comparison of cyclic stress-strain relations by FE analyses with those by tests

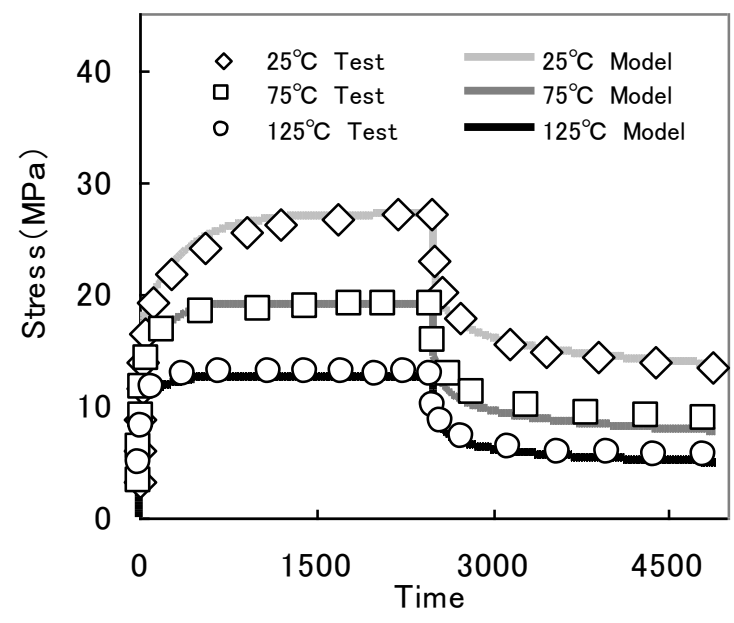

Fig. 8 Comparison of tension stress relaxation-time relations by $\mathrm{FE}$ analyses with those by tests

\section{5. 結 論}

1）温度サイクル負荷に着目して, 温度変化時に生ずる力学的特性と温度保持時に生ずる力学的特性をよく表現 する構成モデルとして，応力ひずみ曲線，応力ひずみヒステリシスループおよび応力緩和曲線を正確に表現 でき，材料パラメータの決定も容易な，粘塑性・クリープ分離型構成モデルを提案した.

2） Sn3.5Ag0.5Cu0.07Ni0.01Ge はんだの引張試験および引張圧縮試験を温度およびひずみ速度を変えて実施し， これらの試験結果から，提案した構成モデルの材料パラメータを決定した。

3）引張試験，引張圧縮試験および引張・応力緩和試験の有限要素解析を行った結果，解析結果と試験結果はい ずれもよく一致した.

\section{文献}

(1) McDowell, D.L., Miller, M.P., and Brooks, D.C., "AUnified Creep-Plasticity Theory for Solder Alloy", Fatigue of Electronic Materials, ASTM STP 1153 , S. A. Schroeder and M. R. Mitchell, eds., American Society for Testing and Materials, Philadelphia, pp. 42-59(1994).

(2) Maciucescu, L.T., Sham, -L., and Krempl, E., "Modeing the Defomation Behavior of a Sn-Pb Soler Alloy Using the Simplified Viscoplasticity Theory Based on Overstress(VBO) “, Transactions of the ASME, Journal of Electronic Packaging, Vol. 121, pp. 92-98(1999).

(3) Tang, H., and Basaran, C., "Damage Mechanics-Based Fatigue Life Prediction Model for Solder Joints", Transactions of the ASME, Journal of Electronic Packaging, Vol. 125, pp. 120-125(2003).

(4) Basaran, C., Zhao, Y., Tang, H., and Gomez, J., "A Damage Mechanics-Based Constitutive Model for Solder Joints", Transactions of the ASME, Journal of Electronic Packaging, Vol. 127, pp. 208-214(2005).

(5) Gomez, J., and Basaran, C., "Damage mechanics constitutive model for $\mathrm{Pb} / \mathrm{Sn}$ solder joints incorporating nonlinear kinematic hardening and rate dependent effects using a return mapping integration algorithm", Mechanics of Materials, Vol. 38, pp. 585-598(2006).

(6) Stolkarts, V., Keer, L.M., and Fine, M.E., "Constitutive and Cyclic Damage Model of 63Sn-37Pb Solder”, Transactions of the ASME, Journal of Electronic Packaging, Vol. 123, pp.351-355(2001). 
(7) Busso, E.P., Kitano, M., and Kumazawa, T., “A Visco-plastic Constitutive Model for 60/40 Tin-lead Solder Used in IC Package Joints", Journal ofEngineering Materials and Technology, Vol. 114, pp. 331-337(1992).

(8) Sung, Y., Luo, G., and Chian, K.S., “A Viscoplastic Constitutive Model for 63Sn37Pb Eutectic Solders”, Transactions of the ASME, Journal of Electronic Packaging, Vol. 124, pp. 91-96(2002).

(9) Fossum, A.F., Vianco, P.T., Neilsen, M.K., and Pierce, D.M., “A Plactical Viscoplastic Damage Model for Lead-free Solder”, Transactions of the ASME, Journal of Electronic Packaging, Vol. 128, pp. 71-81(2006).

(10) 赤松聖文, 中根和彦, 大野信忠, “線形化による高温非弾性構成式の陰的積分”, 日本機械学会論文集 A 編, Vol. 72 , No. 720 (2006-8), pp. 43-50.

(11) 赤松聖文, 大野信忠, 高橋浩之, 川上崇, “非線形硬化を有する分離型構成式の Sn-3.0Ag-0.5Cu への適用” , 日本 機械学会東海支部第 53 期総会講演会講演論文集(2004-3), No43-1,pp.17-18.

(12) Sasaki, K., Ohguchi, K., and Ishikawa, H., "Viscoplastic Defomation of 40Pb/60Sn Solder Alloys - Experiments and Constitutive Modeling”, Transactions of the ASME, Journal of Electronic Packaging, Vol. 123, pp. 379-387(2001).

(13) 大口健一，佐々木克彦，野々山裕芝，田上道弘，“塑性・クリープ分離法の鉛フリーはんだへの適用”，日本機械 学会論文集 A 編, Vol. 69, No. 682(2003-6), pp. 20-27.

(14) Armstrong, P.J., and Fredrick, C.O., "A Mathematical Representation of the Multiaxial Bauschinger Effect”, CEGB Report $\mathrm{RD} / \mathrm{B} / \mathrm{N} 731(1966)$. 